\title{
CREDIBILITY AND CREATIVITY IN NETWORK SOCIETY
}

\author{
Piotr Stanislaw MAZUR ${ }^{1^{*}}$, Piotr DUCHLINSKI ${ }^{2}$ \\ ${ }^{1}$ Jesuit University of Philosophy and Education Ignatianum, Faculty of Philosophy, \\ Department of Philosophy, Ul Mikołaja Kopernika 26, 31-501, Kraków, Poland \\ ${ }^{2}$ Jesuit University of Philosophy and Education Ignatianum, Faculty of Philosophy, \\ Department of Philosophy, Ul Mikołaja Kopernika 26, 31-501, Kraków, Poland
}

Received 13 November 2018; accepted 29 November 2019

\begin{abstract}
The authors of this article claim that the network society is organised around such flow of information in which each entity constitutes its specific centre. Through the network entities obtain information from other entities. The amount of information and the fact that it is difficult to verify it are the reasons why the issue of credibility plays the key role in such a society. Aiming at being credible within the network society involves various methods and techniques of making other entities acknowledge one's credibility. In result credibility is strongly related to creativity. In the pragmatic sense, credibility becomes the objective of creativity. In the moral aspect creativity assumes credibility due to the need to shape a person (education and upbringing) in and by the society in such a way that they may become a creative entity, stimulate their creativity and use it through the interaction with other entities.
\end{abstract}

Keywords: creativity, credibility, ethics, information, moral credibility, network society, pragmatism.

\section{Introduction}

The network society is characterised by the presence of various kinds of information in people's lives and the resulting opportunity of various interactions in the life of individuals and societies. The more varied the interactions and their scopes are, the more difficult it is to evaluate their reliability, as each entity (individual or collective) gives the network its own information on what or who it is, as well as why and how it participates in the network. As the amount of information and entities within the network increases, it is more and more difficult to identify and evaluate their credibility. It is both a theoretical and practical problem. The fact that everyone is free to participate in the network is related to the risk that the network includes a lot of unreliable entities. The decrease of credibility weakens the society and the total lack of credibility destroys it due to the loss of mutual trust among its various entities. That is why, the functioning of a network is facilitated by creativity in searching for the

${ }^{\star}$ Corresponding author. E-mail: piotr.mazur@ignatianum.edu.pl 
ways of verifying and increasing the credibility of entities included in the network. ${ }^{1}$ However, the correlation of credibility and creativity in the network society is much deeper and wider. In order to determine the specific features of this correlation one must understand the nature of the network society and outline the role credibility plays in it. In order to exploration we use philosophical methods; analysis and synthesis, especially ethics methods and reinforce some detailed analysis originated from social science; especially: contemporary psychology and sociology. We also used the case study method for instance Niccolò Machiavelli's. These analyses are preliminary and do not aim at definitive resolution of the problem.

\section{The network society}

According to Manuel Castells, we are witnessing the dynamic process of transformation of traditional societies into information societies. Keeping the cultural and civilisational roots of their identities and the independence from other societies, they are influenced by the informational paradigm produced by the network and by the logic of such paradigm:

"[...] The core processes of knowledge generation, economic productivity, political/ military power, and media communication are already deeply transformed by the informational paradigm, and are connected to global networks of wealth, power, and symbols working under such a logic" (Castells, 2010, p. 20).

The information society is organised around such application of knowledge and information which makes it possible for the users to access and freely influence the process of creating technologies. Castells believes that computers and network create the conditions in which human creativity is released and may freely develop. ${ }^{2}$ Castells does not define the information society underlining that the structure and processes taking place in it cannot be easily described. ${ }^{3}$ Nevertheless, it is a society in which computers and the information network that links them play the key role in organising various aspects of human life. The network not only influences the form of communication of the entities it includes, but it also affects all significant components of human existence. It influences economy, market, employment, social life and even the approach towards fundamental anthropological issues such as the way of thinking about time or death. Thus, the network becomes the tool of transforming and intensifying interpersonal relations, breaking previous limitations resulting from the physical place and time in which people live.

Network society cannot replace the societies that have existed until now but it modifies them, making them a part of the "virtual reality" dynamics. The network is the place in which companies work. It produces a specific kind of culture and it includes institutions and organisations as well as virtual communities. Such communities, as "interpersonal social networks", are subject to "patterns of communication and interaction" that are different from those of physical communities, and they are not as strong as natural communities because they are based on weak bonds. ${ }^{4}$ However, virtual communities are "highly diversified and specialised". Despite that fact, due to their dynamics, they make it possible to "generate reciprocity and

\footnotetext{
${ }^{4}$ Webster claims that "[...] Such superficial, non-disturbing and self-centered links do not merit the term 'community' [...]" (2002, p. 107).
} 
support" (Castells, 2010, p. 365). Therefore, they are real communities which include physical members but do not coincide with them, as a result of which individuals may become the centres of interpersonal relations that were created in such communities.

\section{Collapsing of credibility}

Information revolution has strongly influenced the amount of information published in the network which affects all the entities included in the network. People obtain more and more information from the network, as a result of which the amount of information that comes directly from their sources is decreasing. In this situation the issue of information selection, and especially verifying its source and reliability, is getting more important. The network society may function provided that its particular entities (individual and collective ones) give one another credible information about themselves and the reality.

If the network society's key issue is the fact that each entity becomes a specific information centre that creates relations with other centres, each entity must make itself credible for other entities - within the system of relations (links) that exist in the network. Soo Young Rieh and David R. Danielson underline that the problem of credibility becomes more and more difficult due to such factors as the large amount of information. While until now professionals (editors, reviewers, publishers, news reporters, and librarians) have been responsible for checking the credibility of information, at the moment they are less important because of the amount of information that may be accessed through various systems and resources which are often old, incomplete, badly organised or simply false (Young Rieh \& Danielson, 2007, p. 307). Therefore, it is necessary to continually improve the mechanisms of authorising and evaluating the credibility of entities that constitute and work within the network.

However, we should not only analyse the network, taking into account the amount of available information, but we should also look at the location of both individuals and various social structures in many, often unconscious, relations with other entities. As people find it more and more important to participate in the network society in which the information may change, but never disappear, it is getting more important to learn how to manage one's own credibility. It is not only crucial but also very common since everyone constitutes an information centre which not only participates in others' information but also creates one's own information - if not through its opinions, at least through the traces of activity it leaves within the network. Credibility management, which includes giving or taking it, reducing or improving it, becomes a tool of effective functioning in the network, or even the network policy.

Credibility refers to individuals, but also to countries and international institutions, to economy and finance, politics and culture. The area of interpersonal communication is just a piece of the system of relations created through the network. The network society, due to its commonness and randomness, is constantly exposed to the presence and influence of unreliable entities and insufficiently reliable information, which lowers the general level of trust. Therefore, being in the network requires limited trust to its other users, while the significance of the network requires reinforcing credibility and effective tools of verifying it.

The scale of the possible risk resulting from losing one's credibility was confirmed by the events that took place in the United States in the first decade of the years 2000s. James 
M. Kouzes and Barry Posner note that a lot of political, economic and financial institutions lost their credibility then, which shook the basis of the social order in America. It resulted from lies and other kinds of abuse that contributed to the reduction of employment and the bankruptcy of many social life entities (Kouzes \& Posner, 2011, pp. xii-xiii). In the network society, based on weaker bonds among its particular entities, losing trust is more frequent and easier, but it can also be as costly as in the natural community, taking into account the importance of the network in various areas of human life. It is not easy to improve this situation because it requires, first of all, the restoration of credibility at the level of personal relations. ${ }^{5}$ However, the fact that the network mediates between interpersonal relations may encourage people to take up actions that make the recipient believe in credibility instead of actions that aim at true restoration of credibility. As a result, in the network society the tension between the necessity to become truly credible and the need to make others believe in one's credibility is even more intense than in the physical society. ${ }^{6}$

\section{Credibility - Niccolò Machiavelli’s lesson}

The essential problem with credibility in the network society is clear in the light of the concept of a ruling prepared by Machiavelli and the advice he gives to a prince who wants to rule a country. Machiavelli's suggestions include: 1 ) avoid virtuous actions that may lead to losing one's power (2017, p. 33); 2) avoid only such vices that lead to losing one's power (201, p. 33); 3) "a prince will never be short of legitimate reasons for not keeping his promises" (2017, p. 37); 4) "a deceiver will always find someone who'll let himself be deceived" (2017, p. 38); 5) "a prince needn't have all the good qualities [...], but he does need to appear to have them" (2017, p. 38). Relating Machiavelli's advice to credibility in the public area, one may formulate the following principles: 1 ) one should avoid such kind of (moral) credibility that makes it impossible to fulfil one's objective; 2) one should avoid being not credible only if it makes it impossible to achieve one's objective; 3 ) not keeping one's word may always be legally justified; 4) even what is the most unreliable is credible to someone; 5) it is not necessary to be credible, but it is necessary to appear credible.

Such an approach results in the following conclusions: (1) Credibility is not an inherent good of a person, but is of utilitarian nature. If affirming it makes it difficult to obtain one's objective, one may leave out it. In the social area an example of such a situation may be not informing the recipient about the possible defects (imperfections) of an idea, product or service; (2) The effective limit of accepting unreliability is not the breach of moral credibility, but the impossibility to fulfil the objective which might be achieved if credibility is pragmatically confirmed. From the social point of view, the example of such action may be avoiding inter-

\footnotetext{
5 "But dismissing credibility problems as simply a function of the times permits leaders to escape responsibility for their own actions. The entire economic system is based on trust. It's not based on a particular investment model, price-earnings ratio, income statement, or balance sheet. It's not based on any of these rational concepts. It's based on whether people believe in the numbers and in the people who are supplying them. If people don't trust those who handle their money, their livelihoods, and their lives, they'll just refuse to participate. Leaders must accept that it is their responsibility to take the first step in earning back what has been lost and then further steps to sustain it" (Kouzner \& Posner, 2011, p. iv).

${ }^{6}$ In the conditions of limited credibility and numerous weak relations that make network societies labile, complex strategies of managing the positive or negative credibility of the network entities are getting more important.
} 
acting with someone who has lost their credibility irrespective of whether the person wants to restore it or not. Such a concept may also lead to underestimating moral credibility or ignoring it in deciding about one's actions; (3) In the social area the loss of credibility may be compensated for in various manners. Although it is always possible to find certain arguments or take up certain actions that compensate for the lack of credibility in a subjective way, after crossing the critical point, it is impossible to justify its loss either morally or legally. Ignoring the loss of credibility within the public area has its limits. Referring to Machiavelli's opinion, one may say that if our own credibility is lost it is important to overcome our psychological resistance to the social consequences of the lack of credibility; (4) Finally, it is obvious that such an approach, although it prefers pragmatic unreliability; (5) acknowledges the role of moral credibility in the public area as something without which social life does not exist.

Machiavelli's lesson teaches us that although social reality requires the presence of a moral order, it is not necessary for a person to act in a morally decent manner. Also, credibility, as a part of such an order, is something desirable in interpersonal relations, but - according to such approach - it is not absolutely necessary for a person to be credible. What is necessary, however, is to be able to constantly appear credible in the network society. In this way, credibility is not the result of one aiming at truly having it, but it results from the ability to skilfully use various means and techniques of confirming it. Machiavelli's suggestions may be treated as the manual for obtaining and maintaining credibility of a pragmatic nature. Its key issue is relativisation, though not elimination, of the moral nature of credibility and referring to the pragmatic (functional) aspect.

\section{Pragmatic dimension of credibility}

The pragmatic dimension of credibility is deal with human communication which is taking place in society (see Laar 2007 , p. $317-334)^{7}$. Building credibility is related to using as an effective persuasion means as possible in given circumstances. It is shown by Elliot Aronson who, in the book The Social Animal (2007), which belongs to the social psychology classics, refers to the research carried out by Richard E. Petty and John T. Cacioppo (1984). Aronson claims that there are two basic models of convincing people: the middlemost way and the circumferential way. The former is based on strong arguments confirmed by facts and numbers; the latter is based on using stimuli that encourages people to accept the argument without thorough analysis. Convincing is nothing but another way of obtaining credibility. That is why the middlemost way may be treated as aiming at being credible, while the circumferential way may be treated as aiming at appearing credible.

Based on his analyses, Aronson formulated several basic principles which describe the mechanisms related to obtaining creativity. Such principles are as follows:

"Our opinions are influenced by individuals who are both expert and trustworthy.

A communicator's trustworthiness (and effectiveness) can be increased if he or she argues a position apparently opposed to his or her self-interest.

\footnotetext{
${ }^{7}$ The authors analyse the problem of credibility in the context of critical thinking. In his article they show the pragmatic role of credibility, especially when we are dealing with a pragmatic contradiction (see Laar, 2007).
} 
A communicator's trustworthiness (and effectiveness) can be increased if he or she does not seem to be trying to influence our opinion.

At least where trivial opinions and behaviour are concerned, if we like and can identify with a person, his or her opinions and behaviour will influence our own more than their content would ordinarily warrant.

Again, where trivial opinions and behaviour are concerned, if we like a person, we tend to be influenced even if it is clear that he or she is trying to influence us and stands to profit by doing so" (Aronson, 2007, pp. 83-84). ${ }^{8}$

It is easy to appear credible in the network because of the weak bonds between its entities and related anonymity of those entities, the opportunity to easily change the interaction subjects and the opportunity to easily improve one's network image. At the same time, the stronger our credibility is, the more difficult the consequences of losing it are. Discovering someone's unreliability results in serious image losses, and as a consequence, financial losses too. ${ }^{9}$ Therefore, appearing credible for as long as possible and fighting anything that may expose our unreliability, is a great temptation. ${ }^{10}$ It is often difficult to rebuild lost credibility. Some entities may do it by changing one's identity. It is a much bigger problem for natural persons and large, well-known social entities, such as companies, organisations or countries which cannot renounce or quickly transform their identity.

The functioning of a society assumes the existence of credibility in the moral aspect. The truth is that in the network it is more profitable to be credible than to appear credible. The environment's low trust makes it difficult for an entity to build its credibility and achieve its objectives. Also, confirming the credibility of entities which are only going to appear credible is easier in the reality in which the principles of strong (moral) credibility are valid. However, exposing such unreliability or regaining credibility in the environment which is not credible is not as difficult as in the situation in which strong credibility principles are valid in the society.

We also have to pay attention to the fact that even the pragmatic dimension itself and the weak relations that exist within the network require certain morality. Even if the general principles of credibility are weak, not all the means of making oneself appear credible are morally

\footnotetext{
${ }^{8}$ Aronson extended his conclusions by two more remarks related to credibility in the situation that takes into account the influence on the recipient: "When a communicator has high credibility, the greater the discrepancy between the view he or she advocates and the view of the audience, the more the audience will be persuaded; on the other hand, when a communicator's credibility is doubtful or slim, he or she will produce maximum opinion change with moderate discrepancy" (2007, p. 102). In pragmatic sense we may talking about credibility in the context of ordinary langue. Pragmatics of the ordinary langue is associated with truth and facts witch are interpreted by other language users and experts who informed about different facts. "The credibility of $p$ is what is believed with respect to the truth of $p$, or believed is known, or is in fact known of its truthfulness. Because most so-called "facts" are propositions about phenomena as interpreted by whomever is speaking, we find that so-called "experts" differ as to what the facts are (for instance, with regard to global warming, or what should be done about narcotics, or what is the best linguistic theory)" (Allan, 2012, pp. 230-231).

${ }^{9}$ Such losses were the consequence of the so-called Dieselgate scandal from 2015 related to programming computers used in specifying the level of emissions in Volkswagen cars (see Shepardson, 2017).

${ }^{10}$ Also, it seems that the area in which credibility is shaken plays an important role. If an insurance company loses its credibility, the loss influences the awareness of customers stronger than the loss of the same credibility by a clothes manufacturing company. When human life, health or property is at stake, we require much more credibility. In the area of politics, gaining credibility and questioning the credibility of other subjects is the basic tool of action.
} 
acceptable. It is confirmed by various regulations included in professional ethical codes, e.g. for journalists, managers or doctors. The same also refers to particular communities of the network which require respecting certain rules by those who wish to participate in them and achieve their objectives in them. In the long term, relying only on the pragmatic credibility is ineffective, and breaking the principles of credibility may even lead to excluding someone from a given society. Lowering the level of credibility by disrespecting its moral aspect, results in weakening the mutual trust of the entities that constitute a given society, which limits the influence that persuasion means on those entities. Lower credibility weakens the influence of persuasion means of which credibility is the most important one. ${ }^{11}$

\section{Ethical dimension of credibility}

B. J. Fogg and Hsiang Tseng proposed to distinguish four types of credibility in the process of information: presumed, reputed, surface, and experienced (1999, p. 43). These are not only various kinds, but also degrees of credibility - from the lowest to the highest one. Presumed credibility is a natural openness of some entities towards other entities functioning within the network. ${ }^{12}$ It is definitely weaker than the positive opinion on credibility obtained from second parties. Such opinion, in turn, is weaker than credibility obtained by the network entities which "directly" interact with one another (surface credibility). However, the latter kind of credibility is not yet as strong as credibility of the network entities which completely trust one another (experienced credibility), and aiming at appearing credible (pragmatic aspect) is inseparably linked with aiming at being credible (moral aspect). Nevertheless, such credibility should not be perceived as the negation of other kinds of credibility, but as their justification (rightness) and final fulfilment. It is because each kind of credibility that precedes experienced (actual) credibility refers to it and assumes its existence. However, in this case we should ask ourselves the question what is moral credibility. From the formal point of view, we may treat it as the compliance (eliminating the difference) between aiming at being credible and aiming at appearing credible. But it is not a very clear definition, so it needs clarification.

Credibility is needed everywhere where there is no direct access to the truth about reality, and it is especially important where there are intermediaries with access to the truth. Credibility in the moral sense may be linked with whether a person is truth-telling. If a person is truth-telling, their formal speech (words) or its substitute (attitude or actions) is compliant with the internal order of their thoughts. ${ }^{13}$ Such approach is the Aristotle's golden mean between deficiency (secretiveness as hiding the truth when it needs to be revealed) and excess (the lack of proper delicacy). ${ }^{14}$ Finally, it may be defined as the classical virtue of righteous-

\footnotetext{
${ }^{11}$ E. Cameron Williams observed that the low cost and high credibility of product publicity are the two major advantages it enjoys over other promotional tools (1988, p. 356).

${ }^{12}$ Richard Swinburne indicates that a human being has a natural tendency to believe in their convictions, desires, judgements, thoughts, and memories if there are no reasons for rejecting them (principle of credulity). At the same time, a person has a natural tendency to believe what others communicate (principle of testimony) (2004).

13 "A person who says what is true, utters certain signs which are in conformity with things; and such signs are either words, or external actions, or any external thing" (St. Thomas Aquinas, 2006, p. 2-2, q. 109, a. 1, ad 3).

14 "Excess consists in making known one's own affairs out of season, and deficiency in hiding them when one ought
} 
ness understood as constant and perpetual readiness of the will to render to every man the truth that is due him, which was summed up by Thomas Aquinas as telling the truth when one ought and as one ought ${ }^{15}$. Thus, being truth-telling means rendering the proper degree of truth to anyone who, in given conditions, deserves it. Naturally, not each truth should be rendered to everyone and in all conditions.

If being truth-telling is understood in such a manner, credibility may be defined as the ability to skilfully use one's truthfulness, i.e. such testifying the truth that makes it possible to accept the truth. Such skill (understood as prudence) includes telling the truth as the compliance of one's words, attitudes and actions with one's opinion, and telling it in such a way that it makes it possible for another entity to truly and effectively access the truth that is unavailable to it. Credibility begins in one entity and ends in another one, making it possible for the latter to accept the truth it deserves due to the earned trust. ${ }^{16}$

Although credibility is first of all a moral improvement (to tell the truth when one ought), because of its orientation towards the fulfilment in other entities it includes a pragmatic aspect (to tell the truth as one ought). It also refers to the network society in which pragmatic credibility cannot replace or remove moral credibility - moral credibility is manifested in others through its pragmatic aspect. That is why, effectiveness and morality are not contradictory but they are both aspects of credibility. In the end, moral credibility means adjusting all the means applied to obtain credibility in the pragmatic dimension to aiming at being credible, i.e. becoming a real carrier of truth due to others to such a degree that is possible in relations occurring in the network and in the way those people look for truth in the network.

\section{Credibility and creativity}

The concept of creativity refers to a very complex phenomenon. ${ }^{17}$ That is why there are various theories of creativity (Mumford, 2003). The common perception of this term, which is adopted here, refers to the human ability to apply new ideas or solutions for understanding or processing the reality or acting in this reality. Creativity indicates, on one hand, the existing reality, and on the other hand it indicates human invention which makes it possible for the man to relate to that reality in a creative manner.

to make them known" (St. Thomas Aquinas, 2006, p. 2-2, q. 109, a. 1, ad 3).

15 "On the part of the act, to observe the mean is to tell the truth, when one ought, and as one ought" (St. Thomas Aquinas, 2006, p. 2-2, q. 109, a. 1, ad 3). On the credibility and Thomas Aquinas's concept of truthfulness (see Mazur 2017).

${ }^{16}$ It is obvious that intermediation in the access to truth may facilitate abuse, such as gaining people's trust in order to convince them to something that is not true.

17 “.... Creativity is a complex phenomenon involving the operation of multiple influences as we move from initial generation of an idea to delivery of an innovative new product" (Mumford, 2003, p. 109). In contemporary researches pay attention that creativity is closely related with culture. Today many aspects of creativity are interdisciplinary subject of research. "Creativity and culture, in their own right, are expanding fields of study within the social and human sciences. They are both highly popular notions in a world defined by unprecedented rates of technological progress, connectivity and mobility, as well as existential questions regarding the threats and benefits of globalisation. How do we build cultures that are, at once, global and local, shared yet unique? What is the role played by creativity in this process? How do acts of creativity use culture while, at the same time, renewing it? These are all rather new and yet timely questions" (Glăveanu, 2016, p. 1) 
In the network society there are important relations between credibility and creativity. Credibility is linked with creativity in twofold manner. First of all, creativity, as the basis for the existence and functioning of the society, especially such a weak society as the network community, is the subject of creativity itself. It facilitates the creativity of particular entities which take up various actions aiming at protecting it. In this sense, credibility challenges human creativity. Since the existence and functioning of the network society is based on the credibility of its entities, looking for effective ways of gaining, protecting and verifying credibility is the basic task within the area of the network society protection. It is both a subjective and objective task. Subjectively it is acquiring the skills that support various aspects of credibility where, apart from using traditional persuasion techniques, people are looking for more effective methods and strategies of exerting direct influence on others, as well as the methods of detecting and verifying them, if they are applied. Such creativity may be good or bad, depending on how and why such verification is carried out.

As for the objective perspective, creativity in the network society is oriented at building more and more effective "tools" of credibility authentication and verification within the network. It is in particular visible where the selective access to particular data is important and where entities that carry out various activities in the network, e.g. legal or financial ones, need to protect certain rights of goods. In such areas we may also notice good creativity (creating security systems) and bad creativity (hacking), which are ruled by dialectical rights: fighting and supporting. It is because creativity that aims at building more and more perfect and complicated security systems faces creativity aiming at improving techniques and tools of evading such systems, as a result of which those two kinds of creativity constantly facilitate each other. Such rivalry in the network society is focused on credibility. Both in the subjective and in the objective scope, in both kinds of creativity (good and bad) the problem refers to the pragmatic aspect of credibility.

In the moral sense credibility as the subjective aiming at the prudent way of using one's truthfulness is the basis for human creativity. Proper teaching and making people aware of their mutual responsibility for the network status and for the relations among its entities performs an educational function. Establishing communication standards improves the network culture, facilitating the mutual trust of the network entities. And mutual trust is necessary for learning about the reality and such shaping of a man that shall make it possible for him to take up creative acts. Moreover, today's technical and civilisational development leads to a huge particularisation of knowledge and actions. That is why creative action involves the cooperation of many entities, both in learning about the world and processing it. The network can make those processes much faster due to the rapid exchange of information. Michael Tomasello shows that cooperating with other entities is an important development factor of the whole human race (see 2014). The tool of such development is collective intentionality based on the man's ability to assume the third person's perspective. The influence of second parties, which updates human potentiality, is not a mechanical process but the result of the person's creative attempt to achieve the fullness of their development and to create proper relations with others - also within the network. Mature interpersonal relations and the minimum level of trust for other entities resulting from respecting certain rules are necessary not only for the correct cooperation but also for the mutual competition and rivalry among those entities. 


\section{Conclusions}

The network society is organised around such flow of information in which each entity constitutes its specific centre. The entities included in the network may influence the nature of that information freely. The network is ruled by its own principles and the scope of its influence is so huge that it affects not only on the way of life of individuals and societies, but it also becomes the place and form of social life, embracing the basic areas of human activity.

The network society is organised by the relations in which the network acts as an agent. Through the network society we obtain information from other entities. The amount of information and the fact that it is difficult to verify it are the reasons why the issue of credibility plays the key role in such a society. The total lack of credibility would destroy a society, so social life must be based on a strong (moral) credibility. In this context, aiming at being credible within the network society involves various methods and techniques of making other entities acknowledge one's credibility. However, both of those credibility aspects are complementary to each other. The efficiency of influencing others within the network is better if its entities trust one another, which requires strong credibility, and aiming at being credible, understood as prudent use of one's truthfulness, which requires telling the truth in a way that makes it possible for people to accept it effectively. This is pragmatic aspect of credibility. If was not credibility our everyday life would be destroyed.

In the network society credibility is strongly related to creativity. In the pragmatic sense, credibility becomes the objective of creativity which may be of a different nature and may have various goals (good or bad). Creativity may aim at improving the entity's persuasion skills or the tools of creating or verifying credibility. However, in the moral aspect creativity assumes credibility due to the need to shape a person (education and upbringing) in and by the society in such a way that they may become a creative entity, stimulate their creativity and use it through the interaction with other entities.

\section{References}

Allan, K. (2012). Pragmatics in the (English) Lexicon. In K. Allan \& K. M. Jaszczolt, (Eds.), The Cambridge handbook of pragmatics (pp. 227-250). Series: Cambridge Handbooks in Language and Linguistics. Cambridge: Cambridge University Press. https://doi.org/10.1017/CBO9781139022453.013

Aronson, E. (2007). The social animal. New York: Worth Publishers.

Castells, M. (2010). The information age. economy, society, and culture, 1: The Rise of the Network Society. Oxford: Wiley-Blackwell.

Fogg, B. J., \& Tseng, H. (1999, May 15-20). The elements of computer credibility. CHI '99: Proceedings of the SIGCHI Conference on Human Factors in Computing Systems. SIGCHI Conference on Human Factors in Computing Systems (pp. 80-87). Pittsburgh, Pennsylvania, USA. https://doi.org/10.1145/302979.303001

Glăveanu, V. P. (2016). Introducing creativity and culture, the emerging field. In V. P. Glăveanu (Ed.), The Palgrave handbook of creativity and culture research (pp. 1-12). Series: Palgrave Handbooks. London: Palgrave Macmillan. https://doi.org/10.1057/978-1-137-46344-9_1

Kouzes, J. M., \& Posner, B. Z. (2011). Credibility: how leaders gain and lose it, why people demand it. San Francisco: John Wiley \& S Sons, Inc. https://doi.org/10.1002/9781118983867

Laar, van A. J. (2007). Pragmatic inconsistency and credibility. Argumentation, 21(3), 317-334. https://doi.org/10.1007/s10503-007-9049-8 
Machiavelli, N. (2017). The prince. Retrieved from http://www.earlymoderntexts.com/assets/pdfs/machiavelli1532part2.pdf

Mazur P.S. (2017). Credibility as a Moral Virtue?. Logos i Ethos, 2(46), 35-50. https://doi.org/10.15633/lie.2360

Mumford, M. D. (2003). Where have we been, where are we going? Taking stock in creativity research. Creativity Research Journal, 15(2-3), 107-120. https://doi.org/10.1207/S15326934CRJ152\&3_01

Petty, R. E., \& Cacioppo, J. T. (1984). Source factors and the elaboration likelihood model of persuasion. In Advances in Consumer Research, 11, 668-672.

Shepardson, D. (2017). VW, Robert Bosch agree to pay $\$ 1.55$ billion to Settle U.S. Diesel claims, Reuters. Retrieved from https://www.reuters.com/article/us-volkswagen-emissions-idUSKBN15G3NX

St. Thomas Aquinas. (2006). The Summa Theologica of St. Thomas Aquinas. Retrieved from http:// www.documentacatholicaomnia.eu/03d/1225-1274,_Thomas_Aquinas,_Summa_Theologiae_\%5B1\%5D,_EN.pdf

Swinburne, R. (2004). The existence of God. Oxford: Oxford University Press. https://doi.org/10.1093/ acprof:oso/9780199271672.001.0001

Sulleyman, A. (2017). Here is Facebook's guide to fake news. Independent. Retrieved from https://www. independent.co.uk/news/facebook-fake-news-guide-articles-curate-stop-take-down-lies-russiadonald-trump-us-politics-a7726111.html

Tomasello, M. (2014). A natural history of human thinking. Cambridge, MA: Harvard University Press. https://doi.org/10.4159/9780674726369

Webster, F. (2002). Theories of the information society. Series: International Library of Sociology. Urry, J. (Ed.). London and New York: Routledge. https://doi.org/10.4324/9780203426265

Williams, E. C. (1988). Product publicity: low cost and high credibility, Industrial Marketing Management, 17(4), 355-359. https://doi.org/10.1016/0019-8501(88)90039-9

Young Rieh, S., \& Danielson, D. R. (2007). Credibility: a multidisciplinary framework. Annual Review of Information Science and Technology, 41(1), 307-364. https://doi.org/10.1002/aris.2007.1440410114

\title{
PATIKIMUMAS IR KŪRYBIŠKUMAS TINKLO VISUOMENĖJE
}

\section{Piotr Stanislaw MAZUR, Piotr DUCHLINSKI}

\begin{abstract}
Santrauka
Šio straipsnio autoriai tvirtina, kad tinklo visuomenę organizuoja toks informacijos srautas, kurio sąlygomis bet kokia esatis steigia savąji specifinị centrą. Per tinklą esatys pasiekia informaciją iš kitų esačių. Informacijos kiekis ir faktas, kad sudètinga ją patikrinti, tokioje visuomeneje atlieka pagrindinị vaidmenị. Siekimas būti patikimu tinklo visuomeneje apima įvairius metodus ir technikas, skirtas tam, kad kas nors būtų pripažintas kaip patikimas. Išplaukia, kad patikimumas yra glaudžiai susijęs su kūrybiškumu. Pragmatiniu požiūriu patikimumas tampa kūrybiškumo tikslu. Moralès aspektu kūrybiškumas igauna patikimumo dèl poreikio formuoti asmenị (švietimas ir ugdymas) visuomenèje ir pasitelkiant ją taip, kad tai taptų kūrybine esatimi, žadintų asmens kūrybiškumą ir išnaudotų jị sąveikaujant su kitomis esatimis.
\end{abstract}

Reikšminiai žodžiai: kūrybiškumas, patikimumas, etika, informacija, moralinis patikimumas, tinklo visuomenè, pragmatizmas. 